\title{
RICE STRAW CHOPPING FOR ANIMAL FEED
}

\author{
ARIF, E. M. AND A. A. ELAIWA \\ Ag. Eng. Res. Institute, ARC, Dokki, Giza
}

(Manuscript received 16 June 2009)

\begin{abstract}
Field crop residues are considered among the most variable and important materials in Egypt. The research work conducted at private milking animal farm in Shobak Basta village Zagazig city, Sharkia Governorate to accomplish the machine field work before and after modification. The aim of the present work is to introduce a simple chopper for animal feed suitable for the small holder farm. Also, to measure and calculate the performance, productivity and operational costs. The machine modification was introduced to improve the chopping of rice straw process and increase machine productivity, which was necessary upon field test. The machine modified and manufactured from local materials at a private sector workshop.

Results of this study could be summarized in the following points:

1- The maximum productivity reached $2.85 \mathrm{~kg} / \mathrm{min}$. using two knives, at $4 \mathrm{~mm}$ knives clearance, $18.7 \mathrm{~m} / \mathrm{s}$ cutting drum speed and $16 \%$ rice straw moisture content

2- Using two knives on the cutting drum increased machine productivity than using three or four knives.

3- Cutting efficiency and quality increased by decreasing the clearance and straw moisture content. Meanwhile, cutting length was positive with the clearance.

4- Cutting one ton using the machine costs 23 LE. Meanwhile cutting one ton of rice straw by labor at the same conditions costs $400 \mathrm{LE}$.
\end{abstract}

\section{INTRODUCTION}

Field crop residues are considered as the most abundant resides in Egypt. The total amount of farm residues reached about 38.28 million tons every year (Economics Agricultural Affairs Sector 2006). Rice straw was considered as one of the main problems that face agriculture and will pollute environment in Egypt. Different types of shredding and chopping machines were imported. These machines are different in specifications, performance, characteristics and the purpose of use. Some of those are not suitable for Egyptian conditions. (Abou-Rhya 1967) mentioned that the mechanical cutting aimed to minimize the size of clusters which help the animals to eat the residues easily. So that the cutting or crushing process of field residues become necessary to increase the rate of animal feed. El-Iraqi and El-Khawaga (2003) stated that the maximum percentages in cutting length of less than $5 \mathrm{~cm}$ of 87.80 and $92.00 \%$ were obtained for rice straw and corn stalks residues, respectively, at cutting 
speed of $10.09 \mathrm{~m} / \mathrm{s}$, feeding rate of $0.771 \mathrm{ton} / \mathrm{h}$ and knife clearance of $1.5 \mathrm{~mm}$. And the maximum values of power consumption of 4.90 and $4.76 \mathrm{~kW}$ were obtained at feeding rate of $0.771 \mathrm{ton} / \mathrm{h}$ and cutting speed of $10.09 \mathrm{~m} / \mathrm{s}$ with $4.5 \mathrm{~mm}$ knife clearance for cutting rice straw and corn stalks, respectively. Kholief et al. (1998) mentioned that the lowest value of chopping length was $12.24 \mathrm{~mm}$ at $62.82 \%$ moisture content and $27.65 \mathrm{~m} / \mathrm{s}$ and $0.0068 \mathrm{~m} / \mathrm{s}$ cutter head and feeding mechanism speeds, respectively. Meanwhile, the highest value of chopping length was $18.28 \mathrm{~mm}$ at $40.22 \%$ moisture content and $20.73 \mathrm{~m} / \mathrm{s}$ and $0.024 \mathrm{~m} / \mathrm{s}$ cutter head and feeding mechanism speeds, respectively. Radwan (2000) noted that the machine productivity increased from 508 $\mathrm{kg} / \mathrm{h}$ to $600 \mathrm{~kg} / \mathrm{h}$ for rice straw cutting. Baiomy (1990) stated that the shredding drum speed is considered as the main parameter for shredding process of farm residues. Arif (1999) assumed that the cutting process of farm residues account as the first step in the field of reuse of farm residues. Cutting drum speed, feeding drum speed and the clearance between fixed and rotating knife affect the cutting goodness.

The aim of the present work is to introduce a simple chopper for animal feed suitable for the small farm holder. Also, evaluating the performance, productivity and operational costs.

\section{MATERIALS AND METHODS}

The machine which had been tested in this study was developed and fabricated in a small workshop using local materials.

\section{Machine specifications:}

Feed opening : $18 \times 13 \mathrm{~cm}^{2}$. Drum width : $24 \mathrm{~cm}$.

Overall lengths : $100 \mathrm{~cm}$ Length, $51.7 \mathrm{~cm}$ width and $98.6 \mathrm{~cm}$ height.

Power $\quad: 1.48 \mathrm{~kW}(2 \mathrm{hp})$ electric motor, $1400 \mathrm{rpm}$.

\section{Machine description:}

In this study, the machine used for cutting rice straw (Figs 1 and 2) was constructed in a private workshop at Zagazig city, El-Sharkia governorate under support of special milking animal farm in Shobak Basta village, Zagazig, Sharkia Governorate, to replace the specified machine instead of manual cutting using scissor. The machine consists of a frame, feeding tray, chopping house with outlet opening, power transmission pulleys and $2 \mathrm{hp}$ electric motor. Rice straw is fed manually to the chopping house through feed opening area for cutting process, then the chopped materials fall from outlet opening by the effect of kinetic energy and gravitation behind the machine. 


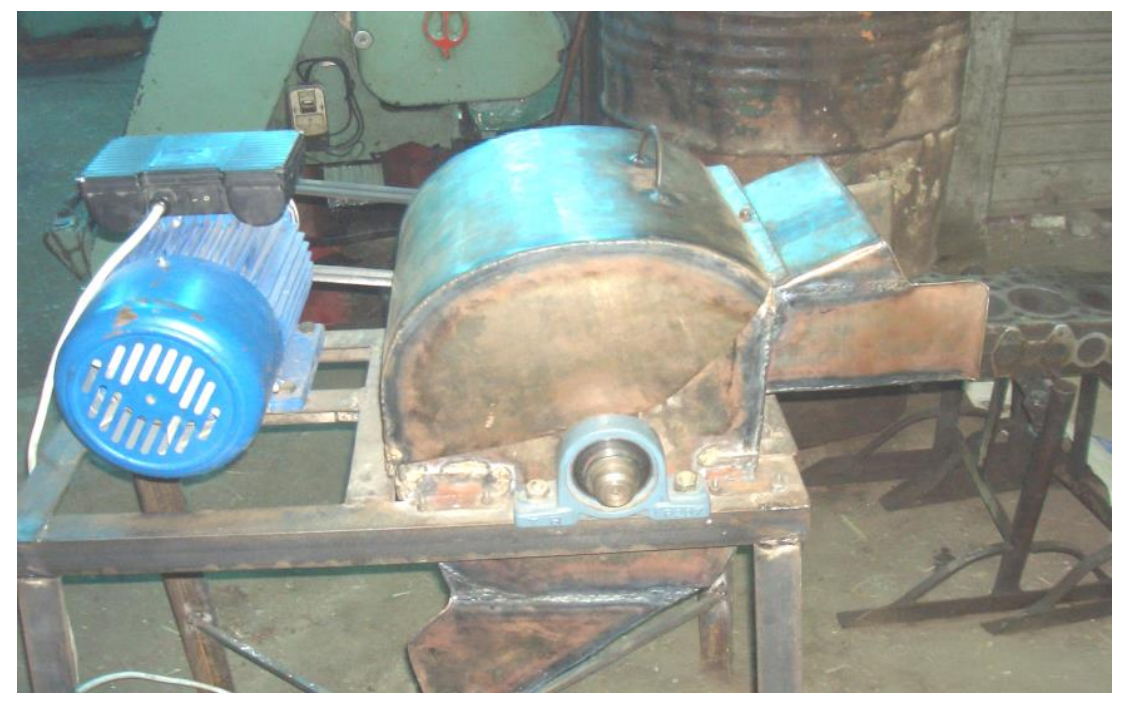

Fig. 1. The developed chopping machine.
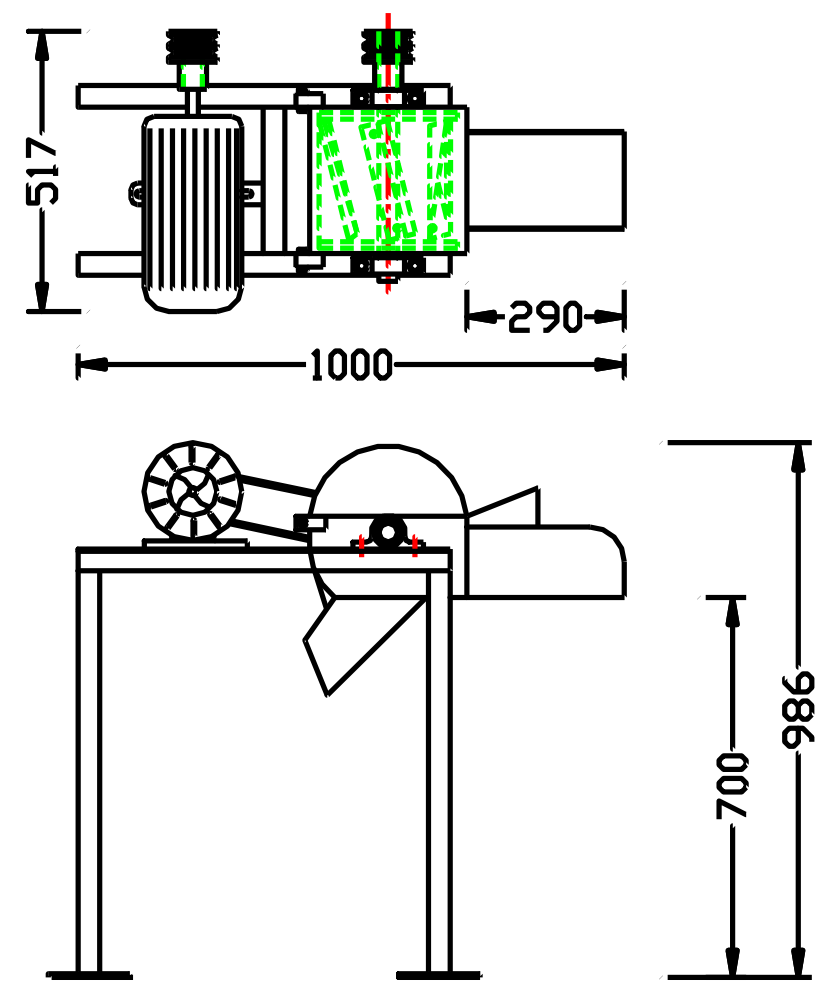

Fig. 2. Sketch of developed chopping machine 


\section{Cutting efficiency:}

Cutting efficiency was calculated by measuring the straw length before and after cutting. Cutting efficiency was calculated according to the following equation (Baiomy, et al., 2007):

$$
\zeta_{c}=\left(L_{b}-L_{a f}\right) / L_{b}
$$

Where:-

$\zeta_{c}=$ Cutting efficiency, $(\%) ;$

$L_{b}=$ Residual length before cutting and

$\mathrm{L}_{\mathrm{af}}=$ Particles length after cutting.

\section{Productivity:}

The machine productivity was calculated as follows:

$P=3600 \mathrm{~W} / \mathrm{t}_{\mathrm{t}}$

Where:

$\mathrm{P}=$ Productivity, $\mathrm{kg} / \mathrm{h}$.

$\mathrm{W}=$ Sample weight after test, $\mathrm{kg}$.

$t_{t}=$ Test time, sec.

\section{Cost analysis:}

The machine operational cost was calculated as follows:

1- Machine cost:

Machine cost is 700 LE (year 2009 prices), the life expectancy of the machine 5 years, and estimated working time 2000 hours per year. Machine cost $=0.07 \mathrm{LE} / \mathrm{h}$.

2- Operational costs:

The operational costs such as labors wage and electric used cost per hour.

3- Taxes and overhead:

Taxes and overhead estimated to be $20 \%$ from machine cost. Total costs $=$ machine cost + operational cost + taxes and over head.

\section{RESULTS AND DISCUSSION}

\section{Productivity:}

Machine productivity was affected by cutting drum speed, knives clearance, numbers of knives on the cutting drum and straw moisture contents as shown in Figs (3 through 6). It's increased from $2.3 \mathrm{~kg} / \mathrm{min}$. to $2.85 \mathrm{~kg} / \mathrm{min}$. by increasing cutting drum speed from $16 \mathrm{~m} / \mathrm{s}$ to $18.7 \mathrm{~m} / \mathrm{s}$, respectively at $4 \mathrm{~mm}$ knives clearance and 16 $\%$ moisture content. And decreased from $2.85 \mathrm{~kg} / \mathrm{min}$. to $2.6 \mathrm{~kg} / \mathrm{min}$. by increasing the moisture content from $16 \%$ to $22 \%$, respectively at $18.7 \mathrm{~m} / \mathrm{s}$ cutting drum speed, and $4 \mathrm{~mm}$ knives clearance. The maximum productivity reached $2.85 \mathrm{~kg} / \mathrm{min}$. 
using two knives, meanwhile it was $1.56 \mathrm{~kg} / \mathrm{min}$. and $1.2 \mathrm{~kg} / \mathrm{min}$. using three and four knives on the cutting drum, respectively at $4 \mathrm{~mm}$ knives clearance, $18.7 \mathrm{~m} / \mathrm{s}$ cutting drum speed and $16 \%$ rice straw moisture content. Machine productivity increased from $1.5 \mathrm{~kg} / \mathrm{min}$. to $2.85 \mathrm{~kg} / \mathrm{min}$. by increasing knives clearance from $1 \mathrm{~mm}$ to $4 \mathrm{~mm}$, respectively at $18.7 \mathrm{~m} / \mathrm{s}$ drum speed, $16 \%$ moisture content and 2 knives on the cutting drum. Generally, the machine productivity increased by increasing drum speed. It may be due to increasing the kinematic energy by increasing the drum speed, which also increased the cutting particles acceleration resulted in improving the cutting process using the combination of impact with shear, also improve the straw egression. Machine productivity was increased by decreasing straw moisture content, which may be due to decreasing the straw elasticity by decreasing the straw moisture content hence improving the cutting operation. Using two knives on the cutting drum increased machine productivity than using three or four knives. This may be due to increasing the distance between the arranged knives on the circumference which reduce straw coiling around the drum circumference and fall through knives and throwed out easily. Meanwhile, using four knives on the cutting drum increased the chance of straw wrapping around the drum circumference specially by increasing straw moisture or/and decreasing drum speed. Machine productivity increased by increasing the clearance, which may be due to increase the density of material between knives (fixed and rotating knives) hence improving the machine feeds.

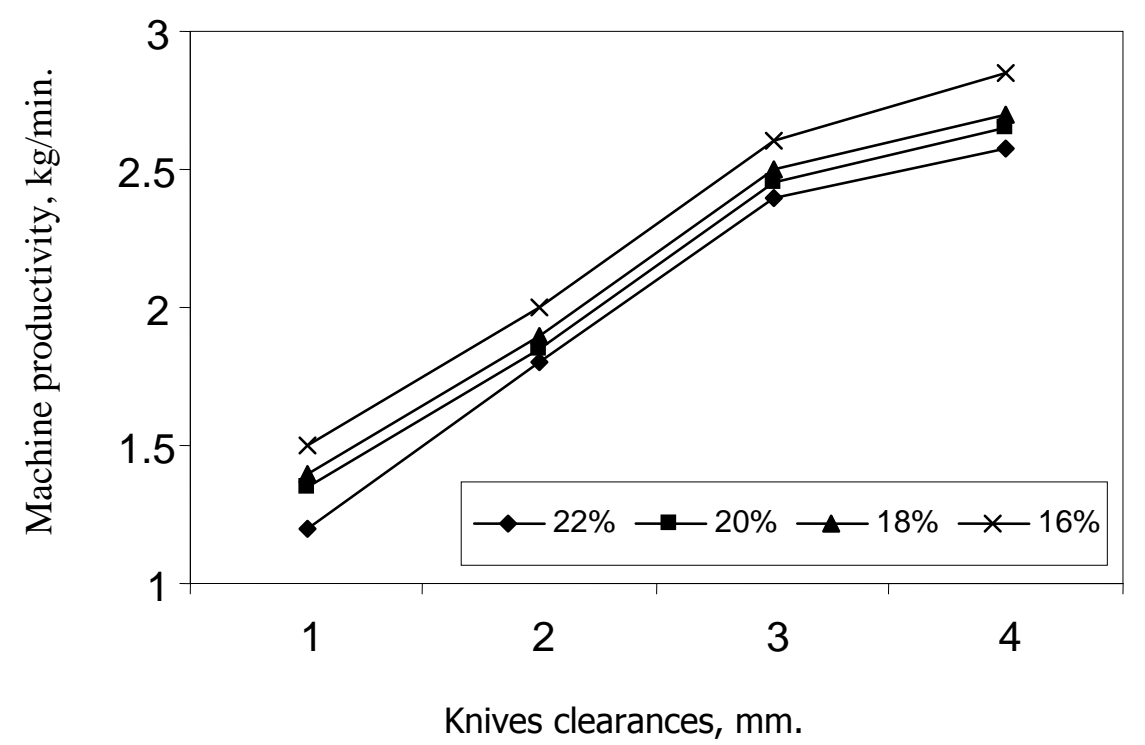

Fig. 3. Effect of knives clearances, $(\mathrm{mm})$ on machine productivity, $(\mathrm{kg} / \mathrm{min}$.) at $18.7 \mathrm{~m} / \mathrm{s}$ drum speed. 


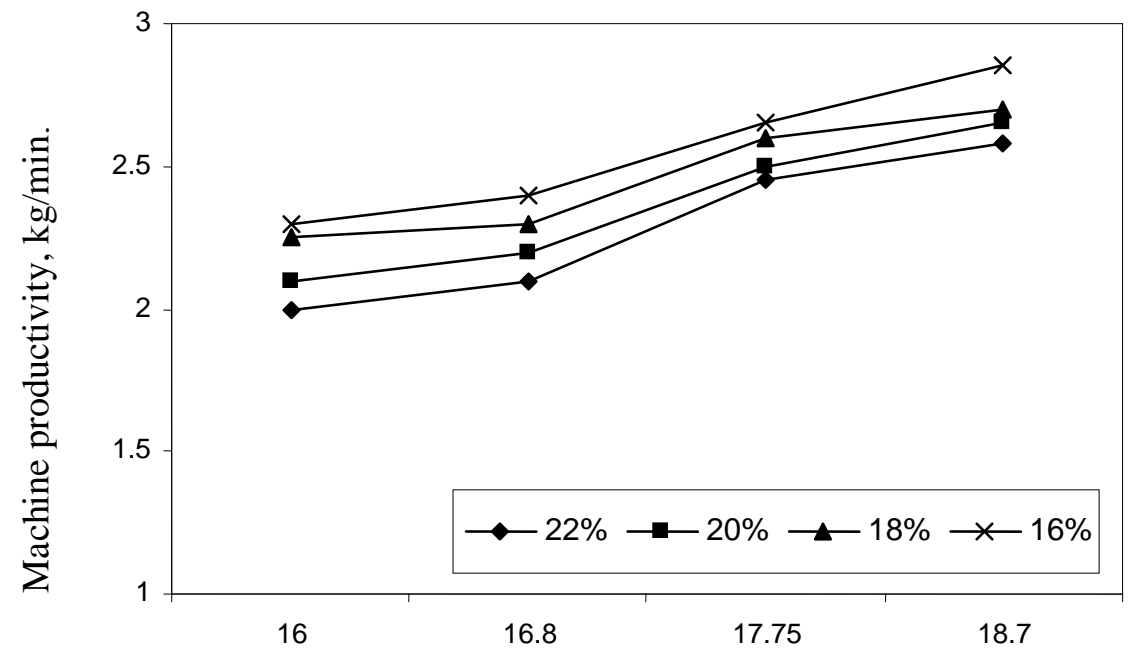

Cutting drum speed, $\mathrm{m} / \mathrm{s}$.

Fig. 4. Effect of drum speed $(\mathrm{m} / \mathrm{s})$ on machine productivity $(\mathrm{kg} / \mathrm{min}$.) using two cutting knives.

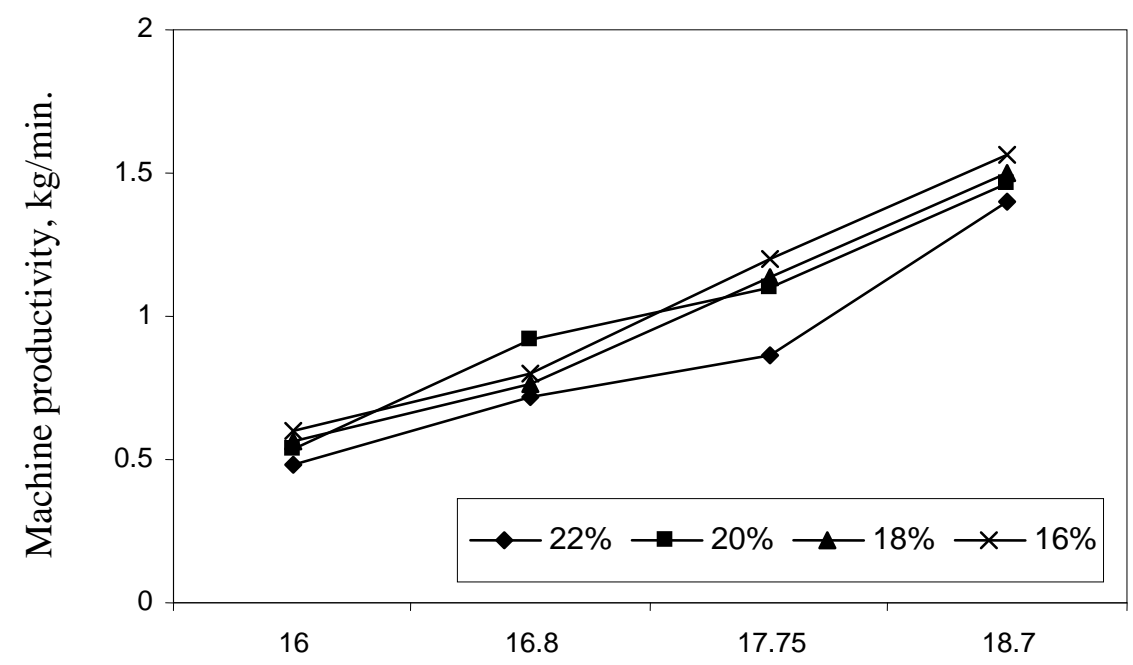

Cutting drum speed, $\mathrm{m} / \mathrm{s}$.

Fig. 5. The effect of drum speed $(\mathrm{m} / \mathrm{s})$ on machine productivity $(\mathrm{kg} / \mathrm{min}$.) using three cutting knives. 


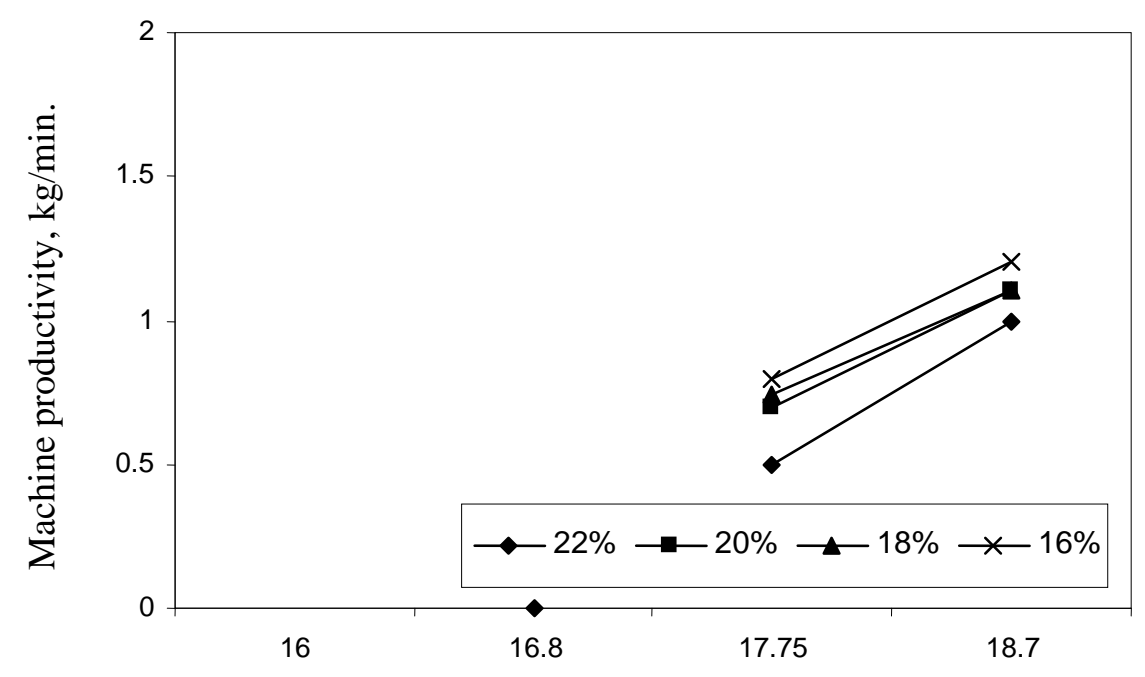

Cutting drum speed, $\mathrm{m} / \mathrm{s}$.

Fig. 6. The effect of drum speed $(\mathrm{m} / \mathrm{s})$ on machine productivity $(\mathrm{kg} / \mathrm{min}$.) using four cutting knives.

\section{Cutting length and efficiency:}

From Figs ( 7 and 8 ) it can be seen that the cutting efficiency increased by decreasing the knives clearance. By decreasing the knives clearance from $4 \mathrm{~mm}$ to $1 \mathrm{~mm}$ the cutting efficiency increased from $67 \%$ to $85 \%$ at $18.7 \mathrm{~m} / \mathrm{s}$ cutting drum speed and using two knives on the cutting drum. Cutting efficiency increased by decreasing the clearance and straw moisture content, it may be due to increase the quality of cut by decreasing the clearance and straw moisture content.

By decreasing the clearance from $4 \mathrm{~mm}$ to $1 \mathrm{~mm}$, cutting length deceased from $13.2 \mathrm{~cm}$ to $6 \mathrm{~cm}$, at $18.7 \mathrm{~m} / \mathrm{s}$ cutting drum speed and using two knives on the cutting drum. Also by decreasing the straw moisture content from $22 \%$ to $16 \%$ the cutting length decreased from $8.9 \mathrm{~cm}$ to $6 \mathrm{~cm}$, at $18.7 \mathrm{~m} / \mathrm{s}$ cutting drum speed and using two knives on the cutting drum. But increasing the clearance decreased cutting quality and unthreading the straw with cutting. 


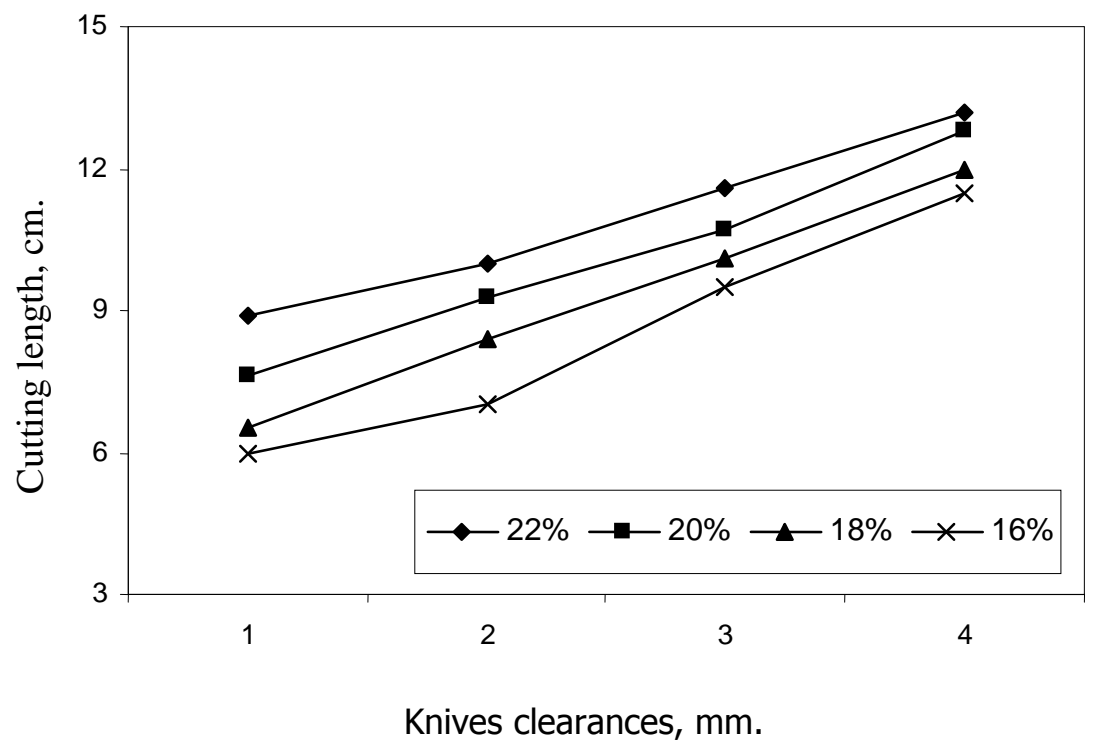

Fig. 7. The effect of knives clearances, $(\mathrm{mm})$ on cutting length, $(\mathrm{cm})$ at $18.7, \mathrm{~m} / \mathrm{s}$ drum speed.

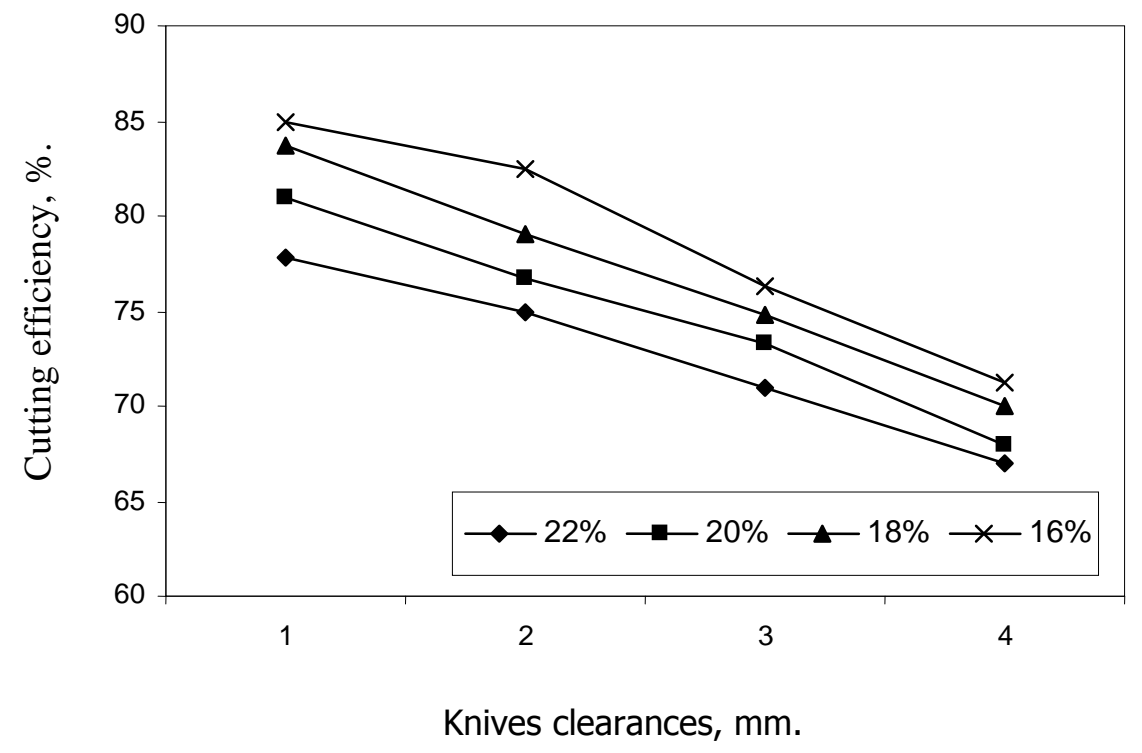

Fig. 8. The effect of knives clearances, (mm) on cutting efficiency, (\%) at $18.7, \mathrm{~m} / \mathrm{s}$ drum speed.

\section{Costs:}

Machine cost was calculated using the following equation.

Total costs $=$ machine cost + operational cost + taxes and over head.

$$
\begin{aligned}
& =0.07+3.56+0.014 \\
& =3.644 \cong 3.7 \mathrm{LE} / \mathrm{h} .
\end{aligned}
$$

Cutting one ton of rice straw using the developed machine costs 23 LE. Meanwhile, it costs $400 \mathrm{LE}$ using labor at the same conditions. 


\section{REFERENCES}

1. Abou-Rhya, A. K. 1967. Feeding animals and nutritional standards and economic relationship. Anglo, Library, Egypt.

2. Arif, E. M. 1999. Development and performance evaluation of a shredder machine for composting, Ph. D. Thesis, Fac. Ag., Ain Shams Univ. :44-78.

3. Baiomy, M. A. 1990. Study on the performance of row crop shredder machine. M. Sc. Thesis, Ag. Eng. Fac. of Ag. Ain Shams Univ.

4. Baiomy, M. A., M. H. A. Kabeel and E. M. Arif. 2007. Development and redesign of crop residue chopping machine. J. Agric. Sci. Mansoura Univ., 32 (9): 7307 7323.

5. El-Iraqi, M. and S. El-Khawaga. 2003. Design and test performance of cutting machine for some crop residues. Misr J. Ag. Eng., 20 (1): 85-101.

6. Kholief, R. M., Z. M. Imara, R. R. Abou-Shieshaa and M. F. Youssef. 1998. Chopping parameters affecting the performance of stationary chopper and silage quality. Misr J. Ag. Eng., 15 (3): 555-568.

7. Radwan, H. A. 2000. Development of small self driven untraditional feed - mill. Ph. D. Thesis, Fac. Agric., Moshtohor, Zagazig University - Benha.

قطاع الشئون الإقتصادية. ج . . r. ثقديرات المحاصيل الزراعية والمخلفات لعام ه . . ب وزارة الزراعة وإستصلاح الأراضى. جمهورية مصر العربية. 


\section{تقطيع قش الأرز لتغذية الحيوانات}

\section{الأمين محمد عارف ، عاطف أحمد عليوة}

$$
\text { معهد بحوث الهنسة الزراعية - مركز البحوث الزراعية - الدقى - الجيزة }
$$

تعد المخلفات الزراعية من أهم المشـاكل التى تواجـه الفـلاح المصرى خاصـة والعالم عامـة،

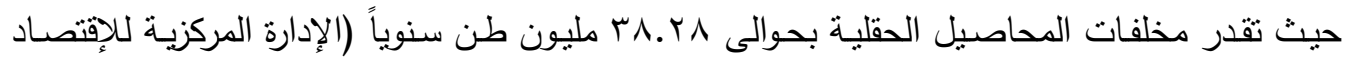

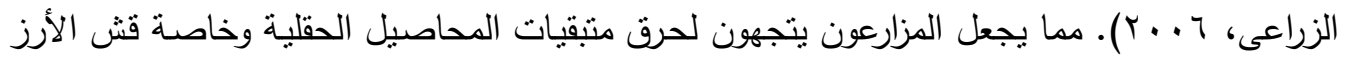
للتخلص منها وسرعة إخلاء الأرض وإعدادها للحصول التالى، الأمر الذى يؤثز بالسلب على البيئة. لذلك يهدف هذا البحث لتصنيع وإختبار آلة بسيطة لتقطيع قش الأرز بغرض التغذية للحيوانات. كانت الأن

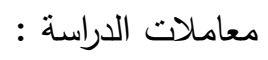
سـرعة درفيل القطع و الخلوص بين السكينة الثابتـة والمتحركة وعدد السكاكين على درفيل القطع

$$
\text { وكانت أهم النتائج كما يلى الرطوبى للقش. }
$$

1- وصلت أعلى إنتاجية للآلة ب. ب. كجم/د بإستخدام سكينتين على درفيل التقطيع، بينما كانت

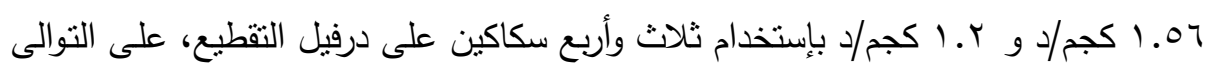

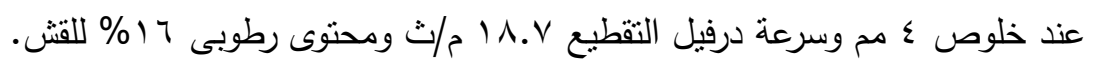
ץ- إرتفعت الإنتاجية للآلة من 1.0

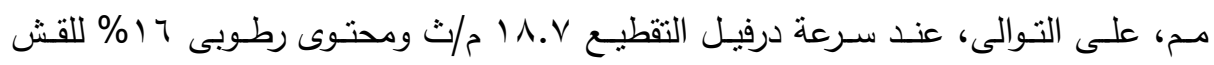
وإستخدام سكينتين للقطع على درفيل التقطيع. r- أرتفعت الإنتاجية بإستخدام سكينتين للتقطيع على درفيل القطع عن إستخدام ثلاث أو أربع سكاكين. ع - إزدادت كفاءة القطع بتقليل الخلوص والمحتوى الرطوبى للقش. وقلت أطوال القطع بإنخفاض الخلوص. بينما بزيادة الخلوص قلت جودة القطع وحدث تتسيل للقش.

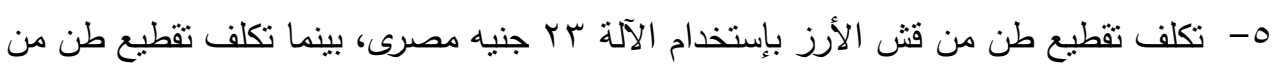

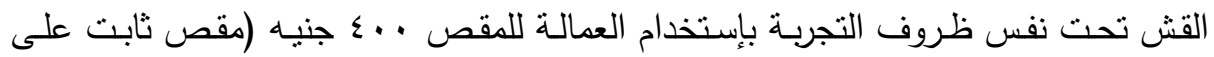
قاعدة خشب كان يستخدم بالمزرعة قبل الآلة). 